\title{
PERMEABILITY OF SALTSTONE - MEASUREMENT BY BEAM BENDING
}

\author{
J. R. Harbour, T. B. Edwards and V. J. Williams \\ Savannah River National Laboratory \\ and \\ George W. Scherer and David M. Feliciano \\ Princeton University
}

October 2007

Process Science and Engineering Savannah River National Laboratory Aiken, SC 29808

Prepared for the U.S. Department of Energy Under Contract Number DEAC09-96SR18500

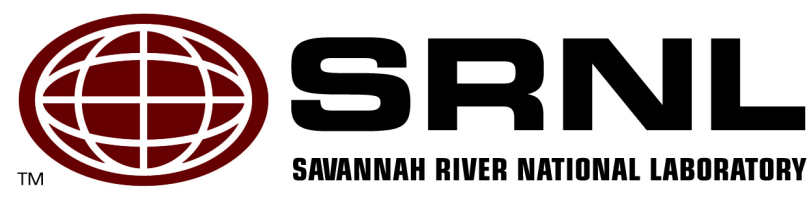




\section{DISCLAIMER}

This report was prepared by Washington Savannah River Company (WSRC) for the United States Department of Energy under Contract No. DE-AC09-96SR18500 and is an account of work performed under that contract. Neither the United States Department of Energy, nor WSRC, nor any of their employees makes any warranty, expressed or implied, or assumes any legal liability or responsibility for the accuracy, completeness, or usefulness, of any information, apparatus, or product or process disclosed herein or represents that its use will not infringe privately owned rights. Reference herein to any specific commercial product, process, or service by trademark, name, manufacturer or otherwise does not necessarily constitute or imply endorsement, recommendation, or favoring of same by WSRC or by the United States Government or any agency thereof. The views and opinions of the authors expressed herein do not necessarily state or reflect those of the United States Government or any agency thereof.

\section{Printed in the United States of America}

Prepared For

U.S. Department of Energy 
Key Words: Hydraulic Conductivity PA

Beam Bending

Retention: Permanent

\title{
PERMEABILITY OF SALTSTONE
}

\author{
J. R. Harbour, T. B. Edwards and V. J. Williams
}

Savannah River National Laboratory

And

George W. Scherer and David M. Feliciano

Princeton University

October 2007

Process Science and Engineering Savannah River National Laboratory Aiken, SC 29808

Prepared for the U.S. Department of Energy Under Contract Number DEAC09-96SR18500

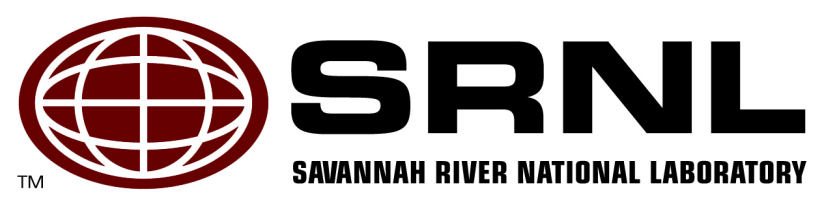




\section{REVIEWS AND APPROVALS}

\section{AUTHORS:}

J. R. Harbour, SRNL, Stabilization Science Research

Date

T. B. Edwards, SRNL, Computational and Statistical Science

Date

V. J. Williams, SRNL, Stabilization Science Research

Date

\section{TECHNICAL REVIEWERS:}

A. D. Cozzi, SRNL, Stabilization Science Research

Date

\section{APPROVERS:}

D. A. Crowley, SRNL, Manager, Stabilization Science Research

Date

R. E. Edwards, SRNL, Manager, Process Science and Engineering

Date

J. E. Occhipinti, Manager, Waste Solidification Engineering

Date 


\section{EXECUTIVE SUMMARY}

One of the goals of the Saltstone variability study is to identify (and, quantify the impact of) the operational and compositional variables that control or influence the important processing and performance properties of Saltstone mixes. A performance property for Saltstone mixes that is important but not routinely measured is the liquid permeability or saturated hydraulic conductivity of the cured Saltstone mix. The value for the saturated hydraulic conductivity is an input into the Performance Assessment for the SRS Z-Area vaults. Therefore, it is important to have a method available that allows for an accurate and reproducible measurement of permeability quickly and inexpensively. One such method that could potentially meet these requirements for the measurement of saturated hydraulic conductivity is the technique of beam bending, developed by Professor George Scherer at Princeton University. In order to determine the feasibility of this technique for Saltstone mixes, a summer student, David Feliciano, was hired to work at Princeton under the direction of George Scherer. This report details the results of this study which demonstrated the feasibility and applicability of the beam bending method to measurement of permeability of Saltstone samples.

This research effort used samples made at Princeton from a Modular Caustic side solvent extraction Unit based simulant (MCU) and premix at a water to premix ratio of 0.60 . The saturated hydraulic conductivities for these mixes were measured by the beam bending technique and the values determined were of the order of 1.4 to $3.4 \times 10^{-9} \mathrm{~cm} / \mathrm{sec}$. These values of hydraulic conductivity are consistent with independently measured values of this property on similar MCU based mixes by Dixon and Phifer. These values are also consistent with the hydraulic conductivity of a generic Saltstone mix measured by Langton in 1985.

The high water to premix ratio used for Saltstone along with the relatively low degree of hydration for MCU based mixes leads to high total and capillary porosities. These two conditions generally lead to higher permeabilities as has been well documented in the literature for typical cementitious pastes in water. Therefore, it is not unexpected that the hydraulic conductivities of these Saltstone mixes are relatively high. 


\section{TABLE OF CONTENTS}

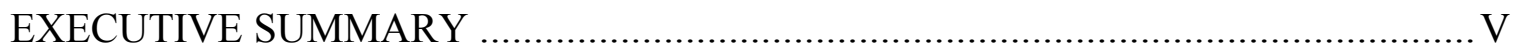

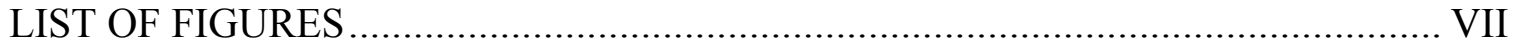

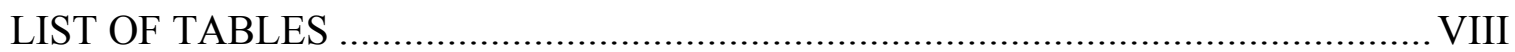

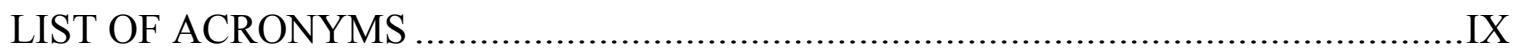

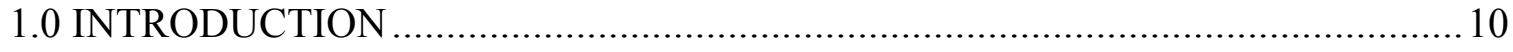

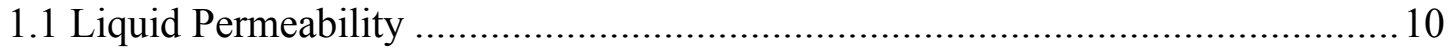

1.2 Conventional Measurement of Permeability .................................................... 11

1.3 Measurement of Permeability by Beam Bending.............................................. 11

1.4 Ordinary Portland Cement in Water Permeability ............................................. 14

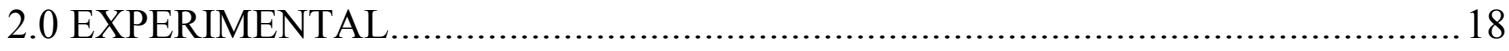

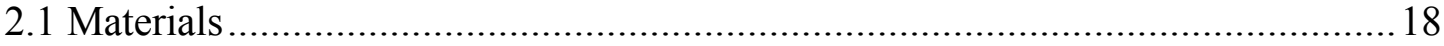

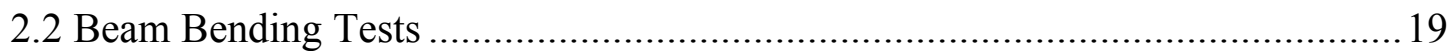

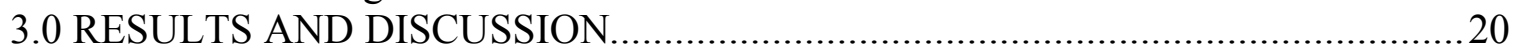

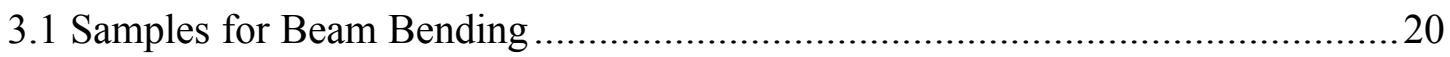

3.2 Results from the Beam Bending Tests........................................................2

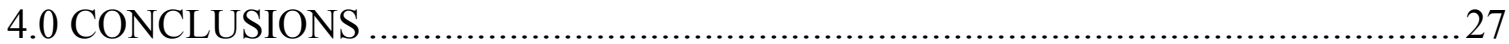

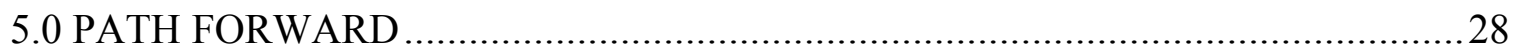

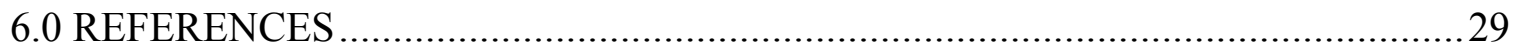




\section{LIST OF FIGURES}

Figure 1-1 Permeameter technique for measuring the hydraulic conductivity 11

Figure 1-2 Diagram showing the beam bending technique exaggerated for effect ${ }^{14}$ 12

Figure 1-3 Results from a beam bending experiment for a portland cement in water paste that has cured for 11 months ${ }^{12}$

Figure 1-4 Reproduction of a figure from Garboczi ${ }^{18}$ that shows the 'fraction connected' as a function of degree of hydration for various $w / c$ ratios

Figure 1-5 Beam bending results for portland cement pastes as a function of time ${ }^{13} \ldots \ldots \ldots \ldots \ldots . . . . . . . .16$

Figure 1-6 Permeability as measured by beam bending vs. total porosity ${ }^{12}$........................... 17

Figure 1-7 Permeability as a function of water to cement ratio from Powers $(1954)^{16}$............. 17

Figure 2-1 Diagram of the experimental setup for the beam bending tests ${ }^{14}$......................... 19

Figure 2-2 Photograph of the beam bending experimental setup (LVDT is a linear variable differential transformer). Photograph from George Scherer at Princeton ${ }^{14}$...................... 19

Figure 3-1 Force relaxation curves for the samples with 5 to $6 \mathrm{~mm}$ thickness ........................ 21

Figure 3-2 Force relaxation curves for the samples with 9 to $10 \mathrm{~mm}$ thickness....................... 21

Figure 3-3 Results for the curve fitting for the force relaxation of the DMF 6-26 sample ......... 22

Figure 3-4 Permeability divided by viscosity of pore solution vs. time................................ 24

Figure 3-5 Compressive strength measurements as a function of cure time on MCU mix at 0.55 water to premix ratio.

Figure 3-6 Young's modulus as a function of cure time on the 5 and $10 \mathrm{~mm}$ samples .............25

Figure 3-7 Heat of hydration data for a MCU in premix grout at 0.60 water to premix ratio...... 26 


\section{LIST OF TABLES}

Table 2-1 Saltstone Cementitious Materials ...................................................................... 18

Table 2-2 Composition of the MCU Mix .......................................................................... 18

Table 2-3 Comparison of Simulant and Saltstone Mix Prepared at Princeton and SRNL .......... 18

Table 3-1 Cast Samples for the Beam Bending Experiments............................................ 20

Table 3-2 Summary of the Results from the Beam Bending Experiments on Saltstone Mixes ... 23

Table 3-3 Average Permeabilities and Hydraulic Conductivities for MCU Mix Plates ............. 23 


\section{LIST OF ACRONYMS}

\begin{tabular}{|l|l|}
\hline ACTL & Aiken County Technology Laboratory \\
\hline CSH & Calcium Silicate Hydrate \\
\hline DMF & David M. Feliciano \\
\hline DWPF & Defense Waste Processing Facility \\
\hline E & Young's Modulus \\
\hline FA & Fly Ash \\
\hline GGBFS & Ground Granulated Blast Furnace Slag \\
\hline GVS & Grout Variability Study \\
\hline HLW & High Level Waste \\
\hline LVDT & Linear Variable Differential Transformer \\
\hline LWO & Liquid Waste Operations \\
\hline MCU & Modular Caustic Side Solvent Extraction Unit \\
\hline NM & Not Measured \\
\hline OPC & Ordinary Portland Cement \\
\hline PA & Performance Assessment \\
\hline SDF & Saltstone Disposal Facility \\
\hline SPF & Saltstone Processing Facility \\
\hline SRNL & Savannah River National Laboratory \\
\hline SRS & Savannah River Site \\
\hline w/c & Water to Cement Ratio \\
\hline w/p & Water to Premix Ratio \\
\hline Wt $\%$ & Weight Percent \\
\hline
\end{tabular}




\subsection{INTRODUCTION}

\subsection{Liquid Permeability}

Liquid permeability is an important performance property of Saltstone that is an input to the Performance Assessment (PA) Models ${ }^{1}$. Liquid permeability is a measure of the flow of liquids through porous media. Saltstone is a highly porous material having total porosities on the order of $60 \% \%^{2}$. If the permeability of Saltstone is high, then water can more readily flow through the waste form and more efficiently transport radionuclide and hazardous components into the Vadose Zone and eventually to the point of compliance. A higher permeability also accelerates the conversion (oxidation) of Tc $(+4)$ to the highly mobile pertechnetate anion Tc $(+7)$, due to the dissolved oxygen in the infiltrating water. The dissolved oxygen not only oxidizes the Tc $(+4)$ but also oxidizes the reducing sites (introduced by slag) in Saltstone. The reducing sites act as a buffer to keep the waste form reducing and technetium in the reduced state ${ }^{3}$. Therefore, the rate at which the total reducing capacity of the Saltstone waste form is diminished will depend on the value of the permeability ${ }^{4}$.

Permeability is defined by Darcy's law

$\mathrm{J}=-\mathrm{k} / \eta \nabla \mathrm{p}$

where $\mathrm{J}$ is the flux (volume/unit area), $\eta$ is the dynamic viscosity of the pore liquid, $\nabla \mathrm{p}$ is gradient in pressure which drives the flow of liquid through the porous medium and $\mathrm{k}$ is the permeability. This equation reveals that $\mathrm{k}$ has units of area and a common unit for permeability is the darcy, which is $10^{-12} \mathrm{~m}^{2}$. For grouts and concretes the permeabilities are normally in the microdarcy to nanodarcy range 5 .

If one replaces the pressure in Equation 1 by hydraulic head ${ }^{5}, \mathrm{~h}$, then the flux can be expressed as $\mathrm{J}=-\mathrm{k}_{\mathrm{w}} \nabla \mathrm{h}$

where $\mathrm{k}_{\mathrm{w}}$ is defined by Equation 3

$\mathrm{k}_{\mathrm{w}}=\mathrm{k} \rho_{\mathrm{w}} \mathrm{g} / \eta_{\mathrm{w}}$

It turns out that, at room temperature, $\mathrm{k}_{\mathrm{w}}(\mathrm{m} / \mathrm{sec})=10^{7} \mathrm{k}\left(\mathrm{m}^{2}\right)$ for water where $\rho_{\mathrm{w}}$ is the density, $\eta_{\mathrm{w}}$ is the viscosity, and $\mathrm{g}$ is the gravitational constant. The permeability, $\mathrm{k}_{\mathrm{w}}$, is then referred to as the hydraulic conductivity. For example, for a grout with a permeability of 1 microdarcy, the corresponding hydraulic conductivity, $\mathrm{k}_{\mathrm{w}}$, is $10^{7} \times 10^{-18}$ or $10^{-11} \mathrm{~m} / \mathrm{sec}$ which is equivalent to $10^{-9}$ $\mathrm{cm} / \mathrm{sec}$. 


\subsection{Conventional Measurement of Permeability}

Typically, permeabilities have been measured using permeameters ${ }^{5}$. In these experiments, water or other liquid is forced under pressure or by ultracentrifugation through the saturated porous media and the flux is measured (Figure 1-1). For porous media with high permeabilities such as typically found in cementitious media, higher pressures are required and this results in longer times of measurements (up to weeks) and difficulties in maintaining a tight seal around the sample (to avoid leakage through the seal and an erroneous value of the permeability). In addition, it is important to ensure that the high pressure does not alter the sample in any way such that the measurement technique changes the permeability that is being measured. Hooten ${ }^{6}$ has written a review on the issues of using a permeameter to measure permeabilities. Phifer et al. $^{7}$ and Dixon and Phifer ${ }^{8}$ have summarized a number of techniques and values of hydraulic conductivity for cementitious based materials.

\section{- Apply pressure difference across sample and measure flux}

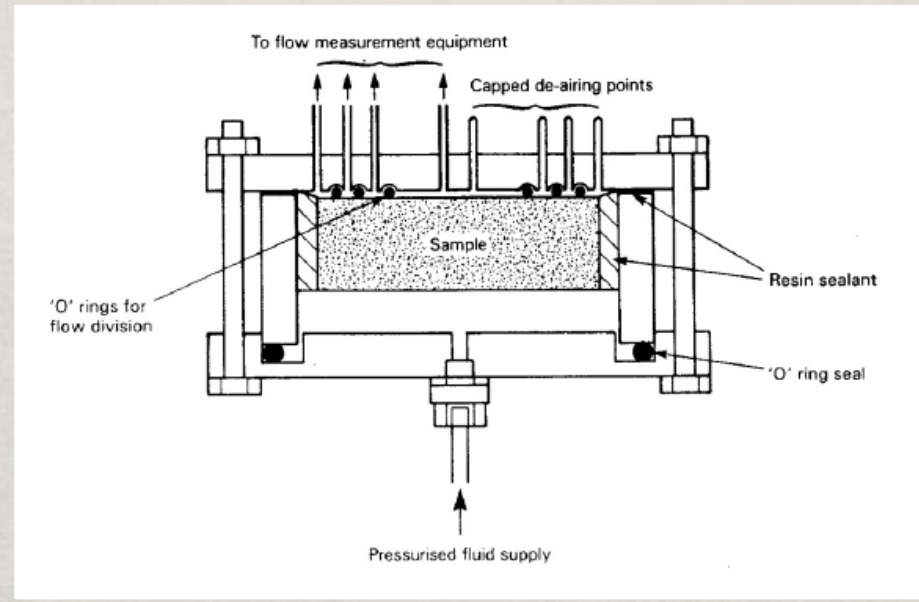

From S.A. Jefferis and R.J. Mangabhai, "The divided flow permeameter", pp. 209-214 in Pore Structure and Permeability of Cementitious Materials, eds. L.R. Roberts and J.P. Skalny, Vol. 137 (Materials Research Society, Pittsburgh, PA, 1989)

Figure 1-1 Permeameter technique for measuring the hydraulic conductivity

\subsection{Measurement of Permeability by Beam Bending}

One goal of the Saltstone variability study is to develop techniques to measure important processing and performance properties as part of the effort to determine the sensitivity of the measured response to the operational and compositional variation that will be experienced during production at the $\mathrm{SPF}^{9}$. Permeability is an important performance property for Saltstone ${ }^{7}$. As 
discussed above, the measurement of permeability (hydraulic conductivity) is difficult and time consuming. Therefore, it is important to have a method available that allows for an accurate and reproducible measurement of permeability quickly and inexpensively. This report details the results of the effort to demonstrate the feasibility of using a novel technique referred to as beam bending for use in measuring the permeability of simulated Saltstone samples. The beam bending technique was developed by Professor George Scherer at Princeton University ${ }^{10}$. This effort was accomplished by funding a summer student from Princeton, David Feliciano, to work in Scherer's laboratory in Princeton and to measure the permeability of samples of grout made using MCU simulant and premix.

The beam bending technique is described in detail in the literature ${ }^{11-13}$. Basically, it is a three point bending setup using a long cylindrical or plate sample (immersed in liquid) in which a force is applied quickly (less than a second) at the center of the sample to produce a deflection in the sample on the order of 50 to 100 microns (Figure 1-2) ${ }^{14}$. The method then measures the reduction in force (with a load cell) with time required to maintain this initial deflection. There are two processes which occur that will allow for the applied force to be reduced and still maintain the deflection. The first is a viscoelastic relaxation within the material itself in response to this force. The time dependence of this relaxation is characterized by the viscoelastic relaxation time. The other process that occurs that also leads to a reduction in the force necessary to maintain this deflection is the flow of liquid within the pores of the sample. After the initial force is applied, the top part of the sample will be in compression (denoted as $\mathrm{C}$ in the Figure) whereas the bottom part will be in tension (denoted as $\mathrm{T}$ in the Figure). This creates a pressure difference between the top and bottom of the sample. Liquid will flow from the top of the sample (higher pressure) to the bottom. Simultaneously, the pore liquid will flow out into the bath solution from the top and into the sample from the bottom. This part of the relaxation is characterized by the hydrodynamic relaxation time.

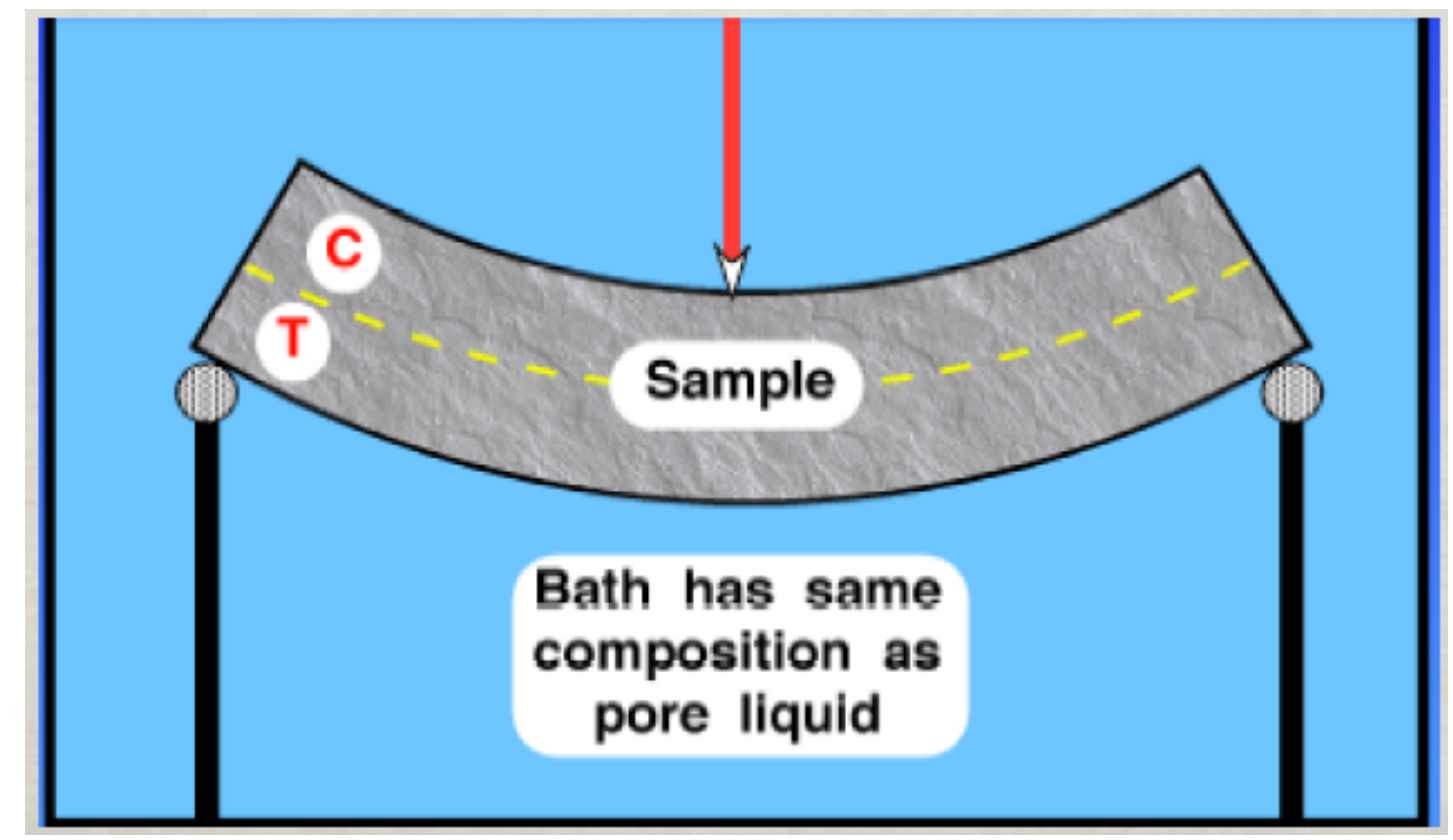

Figure 1-2 Diagram showing the beam bending technique exaggerated for effect ${ }^{14}$ 
Therefore, the relaxation curve obtained experimentally is a sum of the two relaxation processes. In order to obtain the individual curves for each process, a curve fitting must be done such that the sum of the two curves for hydrodynamic and viscoelastic relaxations match the experimental curve 5 . In order to get a good fit to the experimental data it is critical that an inflection point is evident in the experimental curve. Figure 1-3 shows these curves for a portland cement in water paste with a water/cement ratio $(\mathrm{w} / \mathrm{c})$ of $0.60^{12}$. (For Saltstone, the ratio of water to premix is used where premix includes portland cement, blast furnace slag and fly ash.) The actual experimental data is shown by the black dots, the hydrodynamic relaxation is shown by the blue dots, and the viscoelastic relaxation is shown in green. The fit is shown in red and is superimposed on the experimental data. The hydrodynamic relaxation levels off due to the fact that the pressure difference reduces to zero and no further flow can occur. The viscoelastic relaxation continues for longer times as shown in the figure.

\section{- $\mathrm{w} / \mathrm{c}=0.6,11$ months old $k=0.003 \mathrm{~nm}^{2}=3 \times 10^{-14} \mathrm{~m} / \mathrm{s}$ measured in $\sim 5 \mathrm{~min}$}

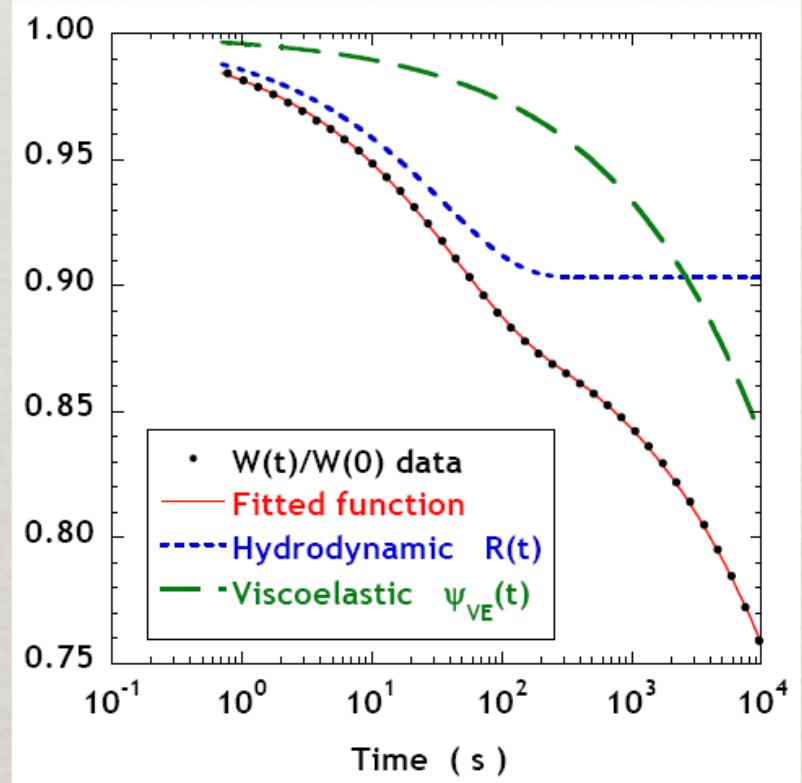

W. Vichit-Vadakan and G.W. Scherer, J. Am. Ceram. Soc. 85 [6] 1537-44 (2002) ; Erratum, 87 [8] (2004) 1615

Figure 1-3 Results from a beam bending experiment for a portland cement in water paste that has cured for 11 months ${ }^{12}$

As part of this curve fitting process, one can calculate Young's modulus from the plateau region and compare its value with an independently measured value of the modulus as a check to ensure that the fit is realistic. Once the hydrodynamic relaxation time has been determined, one can calculate the permeability if the porosity of the grout is independently measured. 


\subsection{Ordinary Portland Cement in Water Permeability}

Liquid permeability in grouts and concrete pastes takes place through the pore structure of the cured $\operatorname{mix}^{15}$. The pore structure is comprised of both nano-sized and micron-sized pores. The micron-sized pores result from capillaries that contain the pore liquid while the nano-sized pores (gel pores) result from the pores within the calcium silicate hydrate $(\mathrm{CSH})$ gel.

For example, a portland cement in water paste with a water/cement ratio of 0.60 starts out with a total theoretical porosity of $68 \%$ prior to the start of hydration reactions and assuming a grout density of $1.82 \mathrm{~g} / \mathrm{mL}$. As hydration occurs, the total porosity decreases as the water consumed in the hydration reactions becomes part of the CSH gel. At an essentially complete degree of hydration, the total porosity has been reduced to $47 \%$ which implies that a water/cement ratio required for complete hydration is 0.185 . At complete hydration, the Powers-Brownyard model $^{16}$ predicts that essentially half of the porosity is from capillaries $(24 \%)$ and half $(23 \%)$ from the nano-sized pores of the $\mathrm{CSH}$ gel ${ }^{15}$. This has been confirmed experimentally ${ }^{17}$.

Garboczi $^{18}$ has pointed out two fundamental concepts involving liquid transport through porous cementitious materials. The first is that large diameter pores have higher transport rates than small diameter pores and the second is that pores that are blocked have zero transport rates, a point that leads to the idea of connectivity of pores.

Connectivity is illustrated in Figure $1-4$ by E. J. Garboczi ${ }^{18}$ at NIST using a computer simulation model of cement paste microstructure. It shows the 'fraction connected' which is defined by Garboczi as "the volume fraction of capillary pores that make up a connected path through the sample divided by the total volume of capillary porosity" as a function of w/c and degree of hydration for a portland cement water paste. When the 'fraction connected' reaches zero the connectivity of the capillary pores also reaches zero and this point is referred to as the percolation threshold. This figure demonstrates that for water to cement ratios of 0.60 and greater, there will always be continuous (percolated) capillary pore structure no matter what the degree of hydration. However, at this stage the micron-sized pores of the capillary structure have been reduced in size generally to values that are below one micron. 
Rev. 0

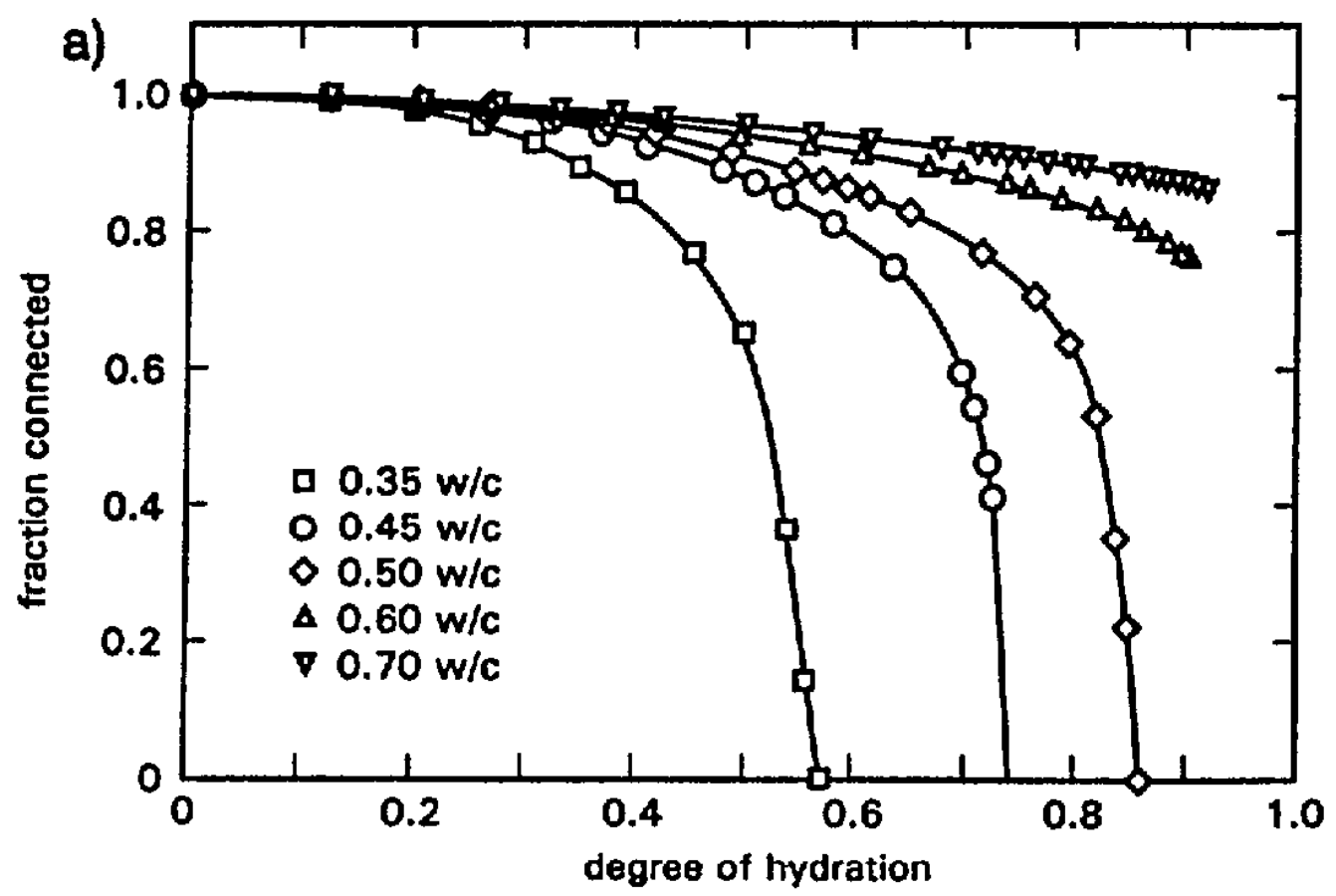

Figure 1-4 Reproduction of a figure from Garboczi ${ }^{18}$ that shows the 'fraction connected' as a function of degree of hydration for various $w / c$ ratios

Even at a $0.50 \mathrm{w} / \mathrm{c}$ ratio, the percolation threshold is not reached until the degree of hydration exceeds 0.80 ( $>80 \%$ of the cementitious material has reacted). It turns out that these curves all suggest a percolation threshold of $18+/-5 \%$ of capillary pore volume. At or below this range, there is no percolation pathway for the porous grout. Although these data are for a portland cement in water mixture, the general principle for dependence of capillary pore connectivity on $\mathrm{w} / \mathrm{cm}$ ratio and degree of hydration should apply to mixed cementitious systems using salt solutions as well.

The data from Figure 1-5 (obtained through the beam bending method) reveal that an OPC water paste with w/c ratio of 0.60 has a hydraulic conductivity of $3 \times 10^{-12} \mathrm{~cm} / \mathrm{sec}$. At this stage, the degree of hydration is close to $100 \%$. For shorter periods of curing time, the hydraulic conductivity depends on the w/c ratio as shown in Figure $1-5^{13}$. For a w/c ratio of 0.55 , the paste has a hydraulic conductivity of $\sim 1 \times 10^{-10} \mathrm{~cm} / \mathrm{sec}$ after only 4 days. 


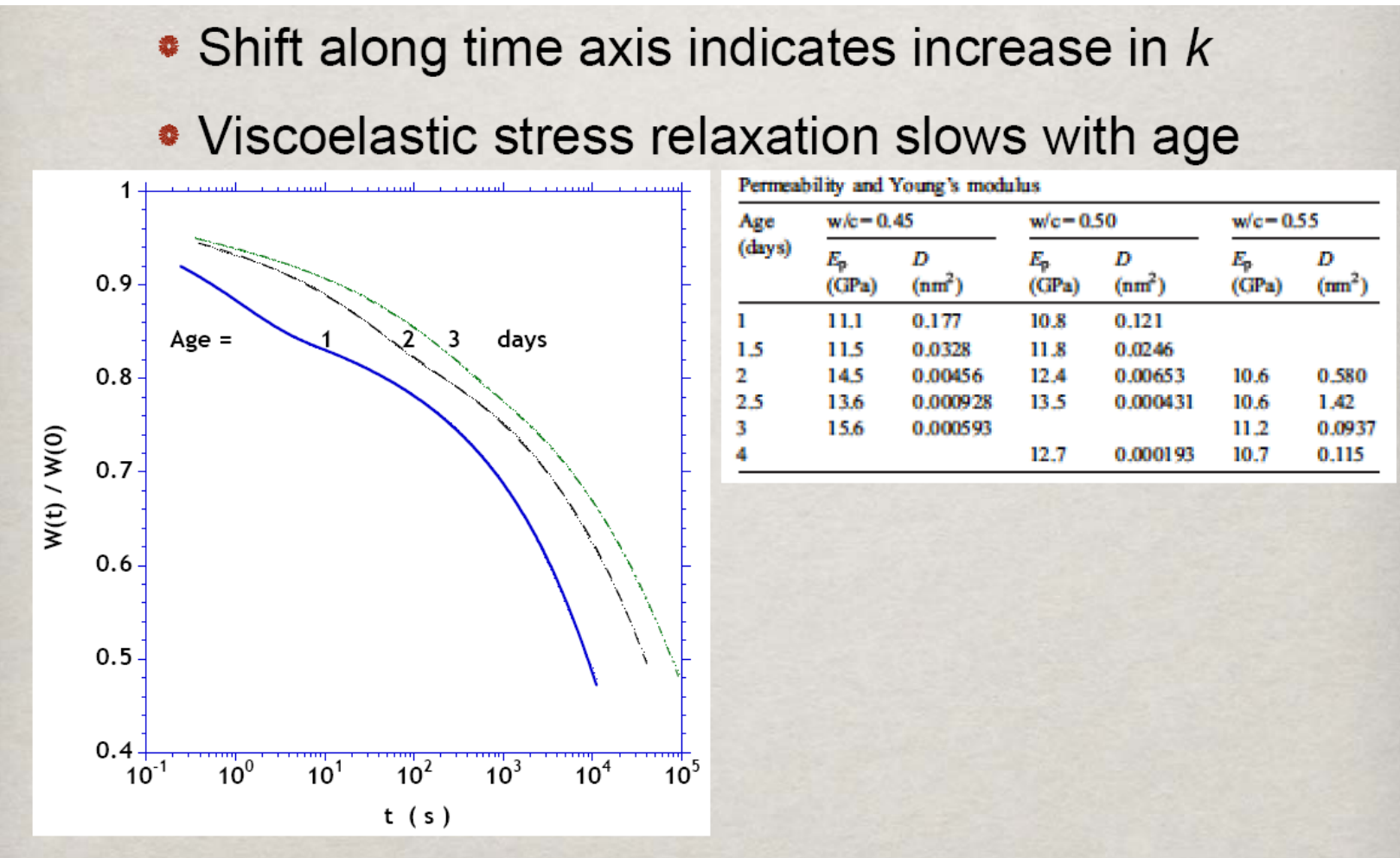

W. Vichit-Vadakan and G.W. Scherer, Cement Concrete Res. 33 (2003) 1925-1932

Figure 1-5 Beam bending results for portland cement pastes as a function of time ${ }^{13}$

The results of permeability versus total porosity are shown in Figure 1-6 for these same pastes at various ages. This general trend in porosity versus permeability was originally shown by Powers in $1954^{19}$ (see Figure 1-7). Therefore, lower permeabilities in grouts can be achieved by reducing the water to cementitious material ratio and by a greater degree of hydration. For Saltstone, a relatively high water to cementitious ratio is used and the degree of hydration is relatively low. For example, Langton ${ }^{20}$ measured the permeability of "Reference Saltstone" sample containing $42.5 \%$ of salt solution and $57.5 \%$ by mass of blended cement in 1986 and reported values for the saturated hydraulic conductivity of $1.1 \times 10^{-8} \mathrm{~cm} / \mathrm{sec}$ for a sample that was cured for approximately 6 months. 


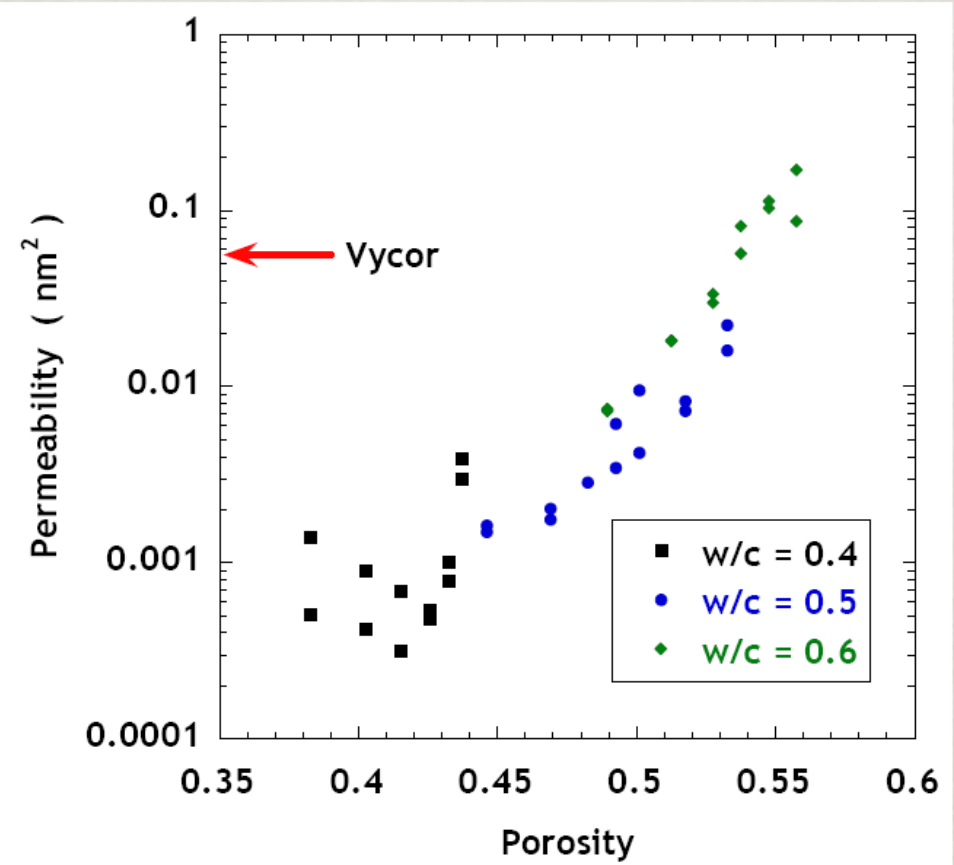

W. Vichit-Vadakan and G.W. Scherer, J. Am. Ceram. Soc. 85 [6] 1537-44 (2002) ; Erratum, 87 [8] (2004) 1615

Figure 1-6 Permeability as measured by beam bending vs. total porosity ${ }^{12}$
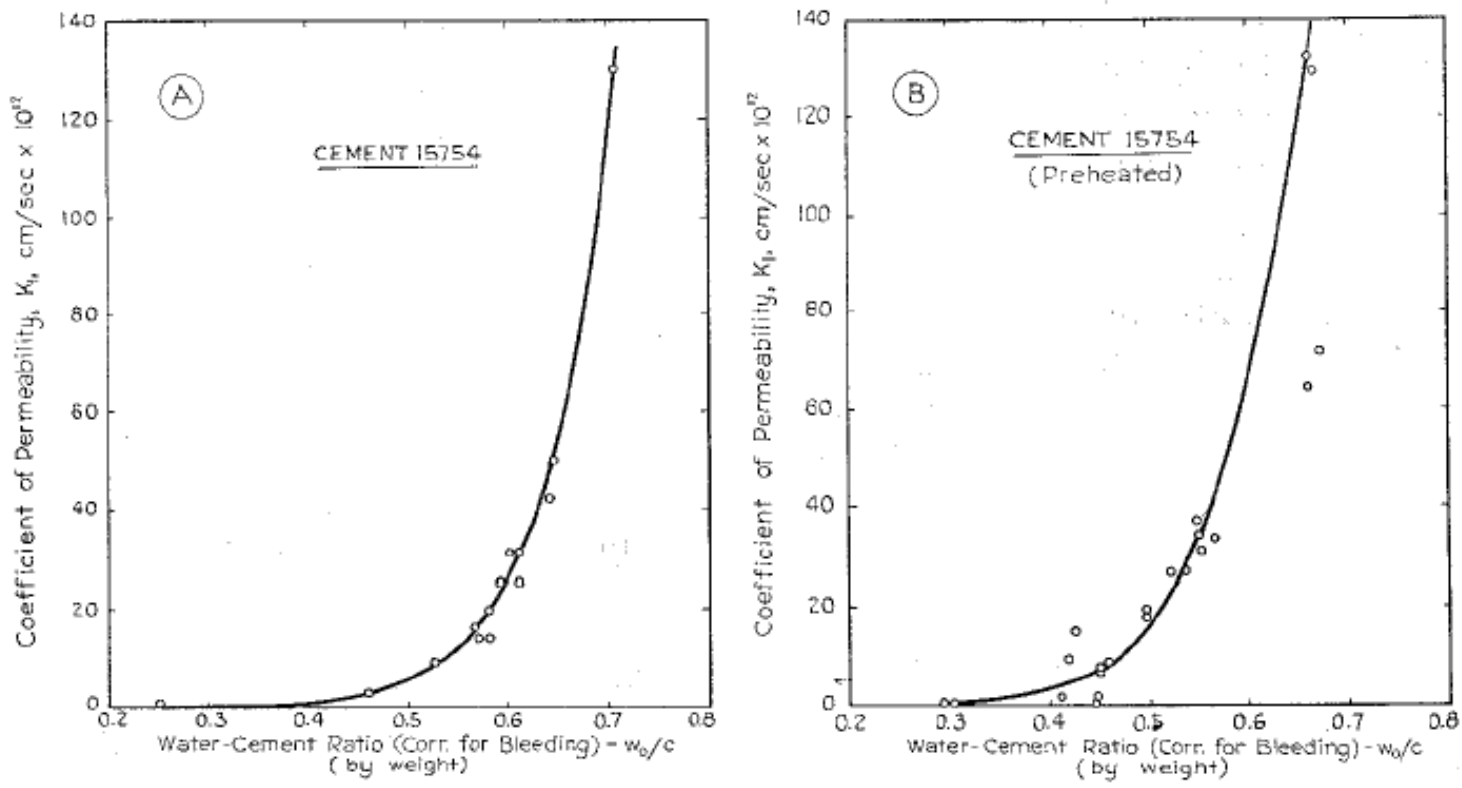

Figure 1-7 Permeability as a function of water to cement ratio from Powers (1954) ${ }^{16}$ 


\subsection{EXPERIMENTAL}

\subsection{Materials}

The cementitious materials were obtained from Saltstone Production Facility (SPF) in 5 gallon containers and are listed in Table 2-1. These materials were specified in a Savannah River Site (SRS) contract for Saltstone cementitious materials and arrived with the delivery of the cementitious materials to Saltstone. The materials were transferred to 2 liter plastic bottles at Aiken County Technology Laboratory (ACTL) and tightly sealed. Maintaining these materials in tightly sealed containers limits the amount of exposure of the materials to air and its associated humidity. Table 2-1 also contains the weight percent (wt \%) contribution of each material used to make the premix.

Table 2-1 Saltstone Cementitious Materials

\begin{tabular}{|c|c|c|c|}
\hline Material & Category & Vendor & Premix Blend (wt\%) \\
\hline Portland cement (OPC) & Type II & Holcim & 10 \\
\hline Blast Furnace slag (GGBFS) & Grade I or II & Holcim & 45 \\
\hline Fly ash (FA) & Class F & Cross Station & 45 \\
\hline
\end{tabular}

The MCU simulant composition is summarized in terms of the key anions of the sodium salts listed in Table 2-2. The mixing was performed as previously described using a paddle blade mixer (6-blade Rushton impeller) with a three minute mixing duration". This simulant differed slightly from the simulant used by Dixon and Phifer in that no phosphate (at $0.012 \mathrm{M}$ ) or solvent to simulate carryover from the MCU process (100 microliters per 1600 gram batch) were added.

Table 2-2 Composition of the MCU Mix

\begin{tabular}{|c|c|c|c|c|c|c|}
\hline $\begin{array}{c}\text { Aluminate } \\
(\mathbf{M})\end{array}$ & $\begin{array}{c}\text { Free } \mathbf{O H}^{-} \\
(\mathbf{M})\end{array}$ & w/premix & $\begin{array}{c}\text { Nitrite } \\
(\mathbf{M})\end{array}$ & $\begin{array}{c}\text { Nitrate } \\
(\mathbf{M})\end{array}$ & $\begin{array}{c}\text { Carbonate } \\
(\mathbf{M})\end{array}$ & $\begin{array}{c}\text { Sulfate } \\
(\mathbf{M})\end{array}$ \\
\hline 0.05 & 1.39 & 0.60 & 0.37 & 3.16 & 0.176 & 0.059 \\
\hline
\end{tabular}

The properties of the simulant and grout prepared at Princeton were compared to the properties of the simulant and grout prepared independently at the Savannah River National Laboratory (SRNL) and the results are summarized in Table 2-3.

Table 2-3 Comparison of Simulant and Saltstone Mix Prepared at Princeton and SRNL

\begin{tabular}{|c|c|c|c|}
\hline Property & SRNL & Princeton & \% Difference \\
\hline Density of MCU & $1.26 \mathrm{~g} / \mathrm{mL}$ & $1.25 \mathrm{~g} / \mathrm{mL}$ & $0.79 \%$ \\
\hline Viscosity of MCU & $2.42 \mathrm{cP}$ & $2.50 \mathrm{cP}$ & $3.31 \%$ \\
\hline Cured Grout Density & $1.79 \mathrm{~g} / \mathrm{mL}$ & $1.75 \mathrm{~g} / \mathrm{mL}$ & $2.23 \%$ \\
\hline Porosity & $62 \%$ & $63 \%$ & $1.60 \%$ \\
\hline
\end{tabular}




\subsection{Beam Bending Tests}

The methods used for the measurements of both fresh and cured grout properties have been discussed previously and were used for this report. Figure 2-1 shows a diagram of the experimental setup while Figure 2-2 shows a photograph of the setup ${ }^{14}$. In the diagram, LVDT refers to Linear Variable Differential Transformer, a type of electromechanical transducer that can convert the motion of an object to which it is mechanically coupled to an electrical signal.

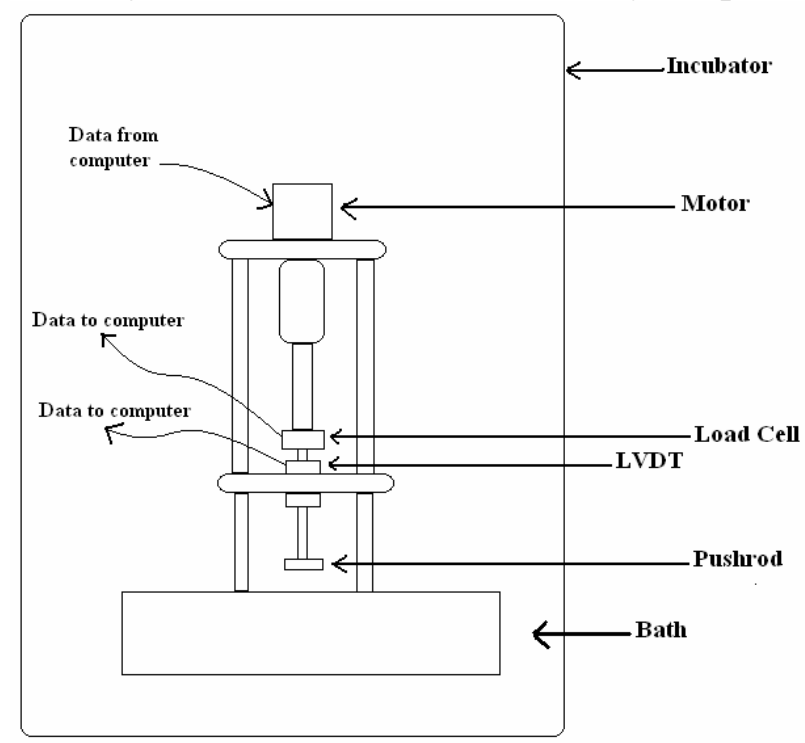

Figure 2-1 Diagram of the experimental setup for the beam bending tests ${ }^{14}$

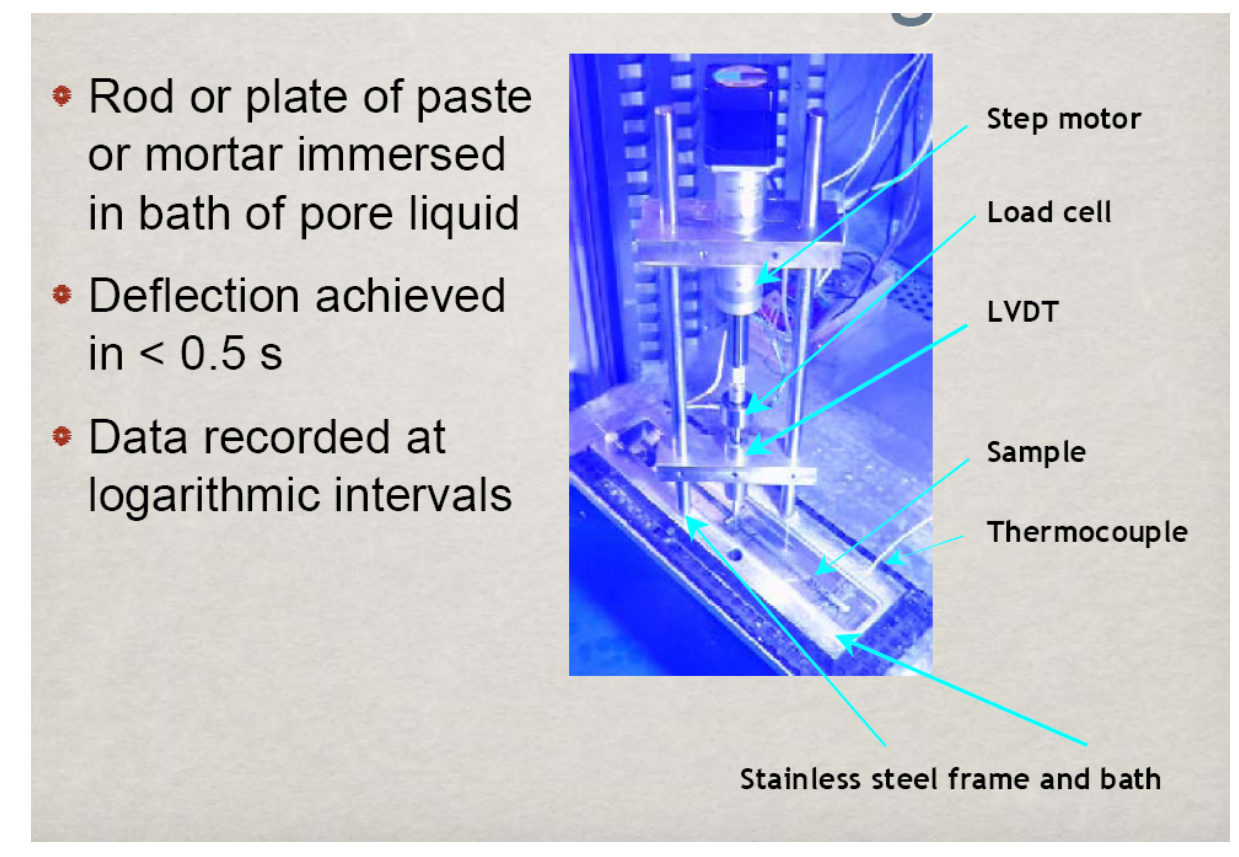

Figure 2-2 Photograph of the beam bending experimental setup (LVDT is a linear variable differential transformer). Photograph from George Scherer at Princeton ${ }^{14}$ 


\subsection{RESULTS AND DISCUSSION}

The permeabilities of samples cast from the MCU mixes at a 0.60 water to premix ratio are presented in this section. The 'plates' that were cast had two different thickness ranges, nominally 5-6 mm and 9-10 $\mathrm{mm}$. These data were obtained from samples cast and measured by David Feliciano, a senior at Princeton University. The work was performed at Princeton under the direction of Professor George Scherer. The figures and tables related to beam bending tests were supplied by Feliciano and Scherer. The data on compressive strength and heat of hydration were obtained at SRNL.

\subsection{Samples for Beam Bending}

The cast sample dimensions and dates of preparation for the MCU simulant mixes are provided in Table 3-1. The cast samples are approximately $28 \mathrm{~cm}$ in length, 21 or $25 \mathrm{~mm}$ in width, and between 5 and $10 \mathrm{~mm}$ thick. Care was taken to keep the samples wet using the simulant to wet the surface. Once the samples were removed from the molds, the plates were placed in a bath of the MCU simulant until the time of the measurement. The measurements were made in a bath in which the sample was immersed in the MCU simulant.

Table 3-1 Cast Samples for the Beam Bending Experiments

\begin{tabular}{|c|c|c|c|c|}
\hline Sample Name & Avg. Thickness $\mathbf{( m m})$ & Width $\mathbf{( m m})$ & Date Prepared & Marking \\
\hline DMF_6-26_6mm & 6.66 & 20.38 & $6 / 26 / 2007$ & $\mathrm{I}$ \\
\hline DMF_6-26_10mm & 9.40 & 20.41 & $6 / 26 / 2007$ & $\mathrm{II}$ \\
\hline DMF_6-26_5mm & 4.84 & 25.40 & $6 / 26 / 2007$ & $\mathrm{IV}$ \\
\hline DMF_6-26_9mm & 9.43 & 20.34 & $6 / 26 / 2007$ & $\mathrm{III}$ \\
\hline DMF77-3_6mm & 6.54 & 20.21 & $7 / 3 / 2007$ & $\mathrm{VI}$ \\
\hline DMF_7-3_10mm & 10.24 & 21.36 & $7 / 3 / 2007$ & $\mathrm{~V}$ \\
\hline
\end{tabular}

\subsection{Results from the Beam Bending Tests}

The permeability results of the beam bending tests for the 5-6 mm thick samples and the 9-10 mm thick samples are shown in Figures 3-1 and 3-2. The curves all show the characteristic inflection point which is a requirement in order to extract the hydrodynamic relaxation time and the permeability with confidence. These curves all showed that the hydrodynamic relaxation plateaus after approximately one second of relaxation. This is much faster relaxation than observed for OPC in water pastes at short and longer time periods (Figures 1-3 and 1-5). 
WSRC-TR-2007-00437

Rev. 0

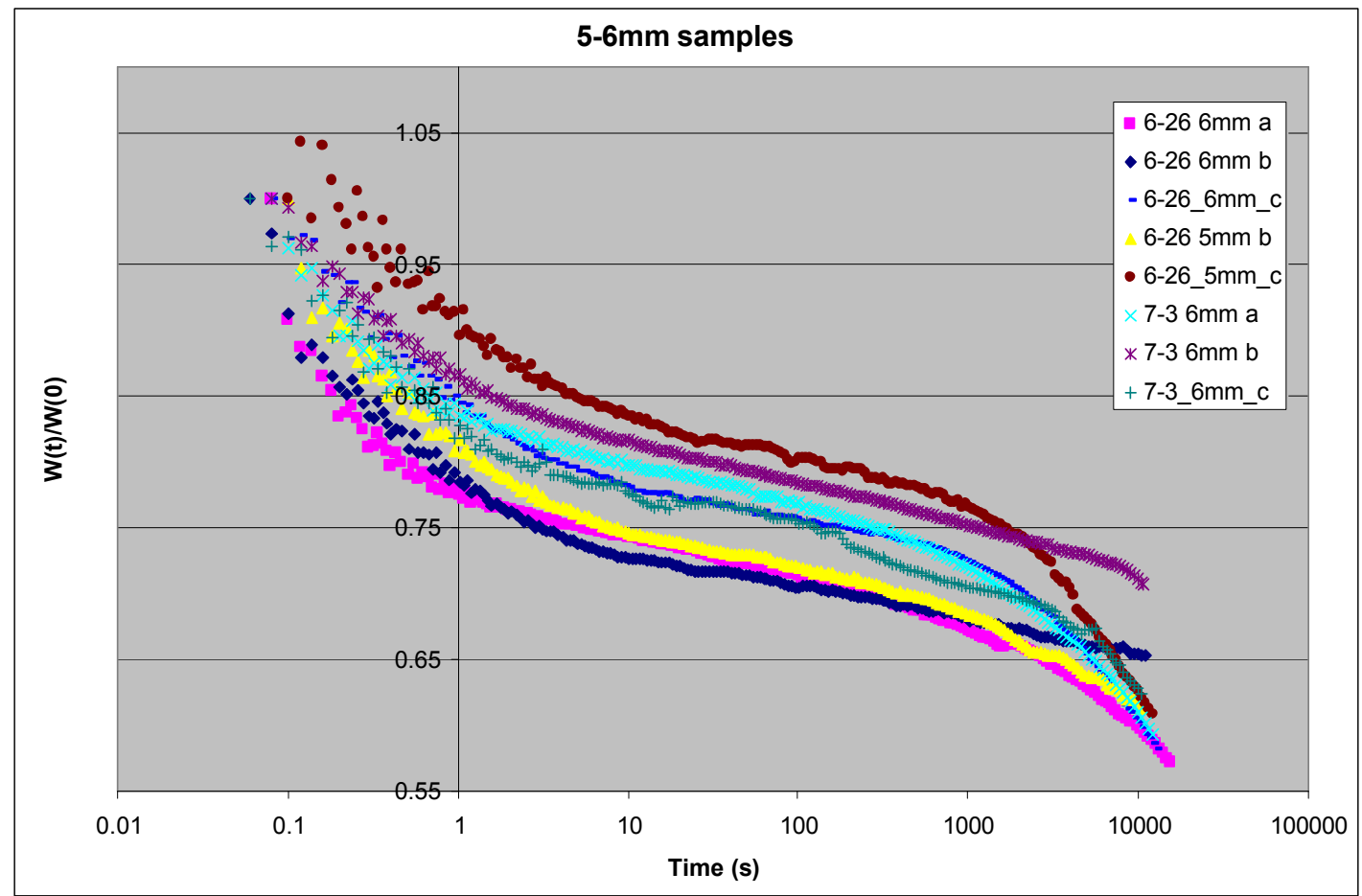

Figure 3-1 Force relaxation curves for the samples with 5 to $6 \mathrm{~mm}$ thickness

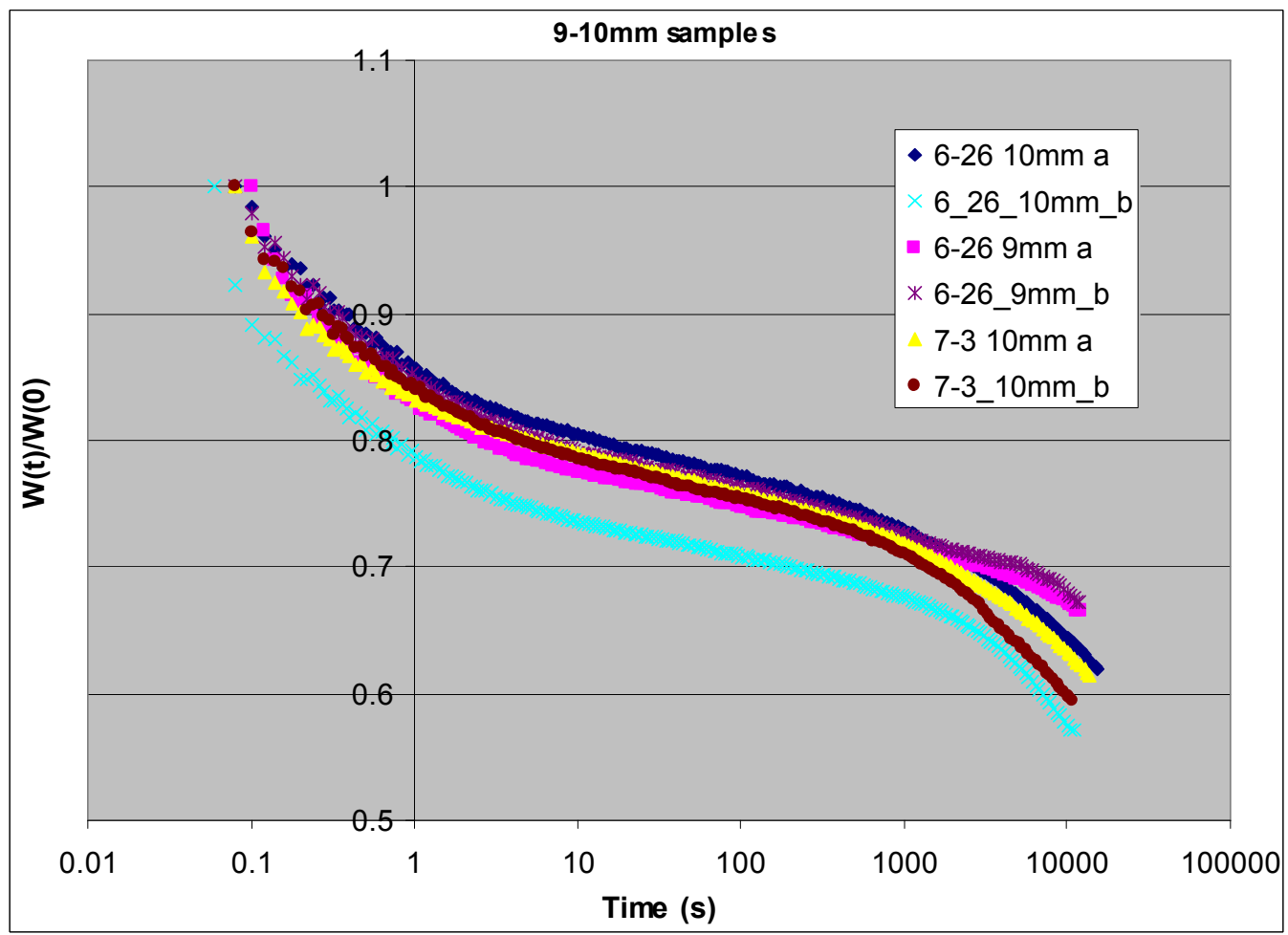

Figure 3-2 Force relaxation curves for the samples with 9 to $10 \mathrm{~mm}$ thickness 
Figure 3-3 shows the relaxation curve (blue circles) of one of the samples (DMF_6-26_10mm) and the curve that fits this data in red. At 0.01 seconds, the hydrodynamic relaxation has reduced the force necessary to maintain the deflection by $\sim 7 \%$. This fast response shows that the medium is very porous and the liquid flows quickly within the pores. The normalized force reduction due to the hydrodynamic relaxation is also relatively large which indicates that more liquid has flowed to reduce the force than with normal OPC water mixes. This is consistent with the higher porosities and higher quantities of liquid present in these Saltstone mixes.

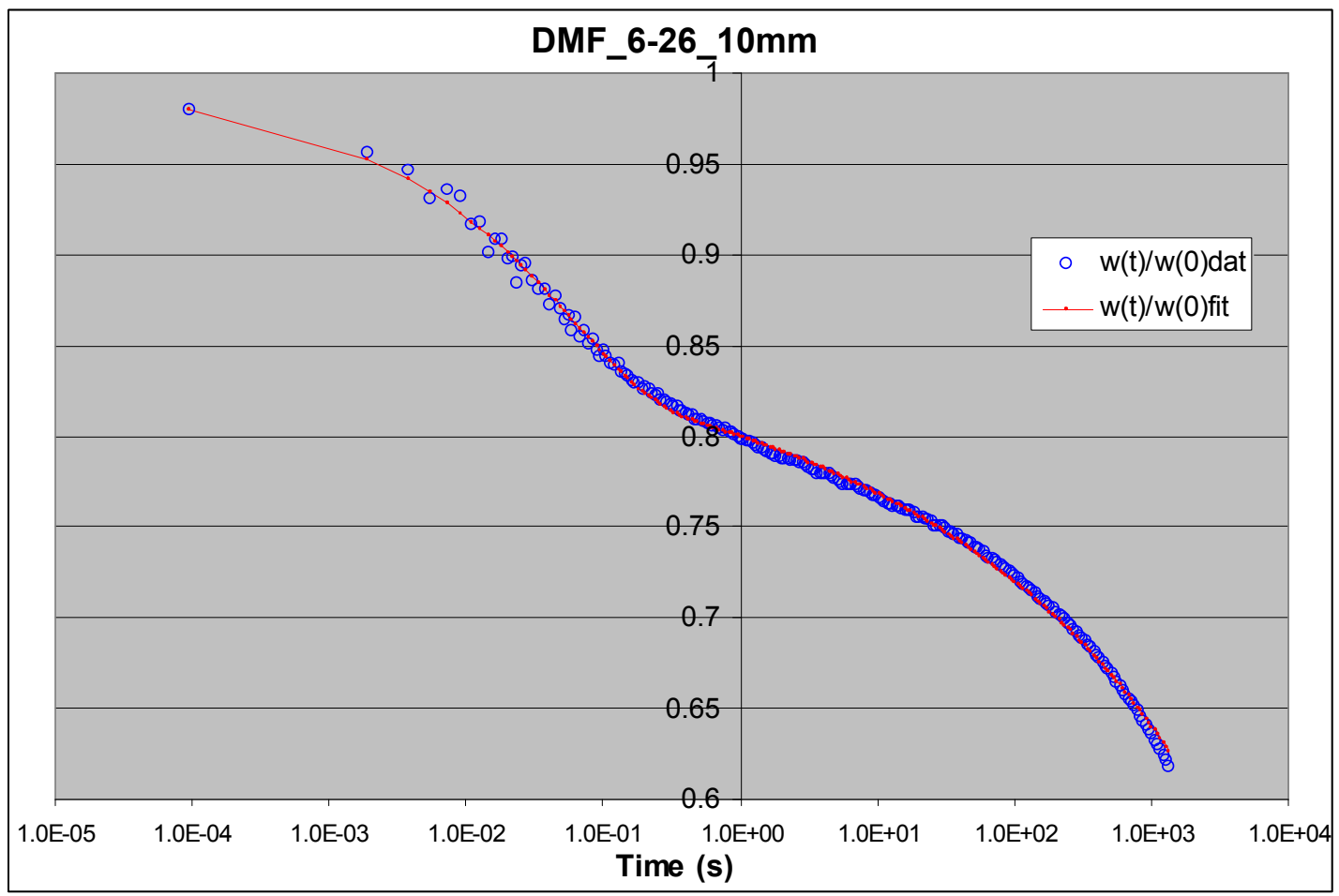

Figure 3-3 Results for the curve fitting for the force relaxation of the DMF 6-26 sample

The results for all the samples obtained from the curve fitting are provided in Table 3-1. The measurements were performed twice on each sample so two results are presented for each sample for each day it was measured. There is good correspondence between the values for Young's Modulus $(\mathrm{E})$ obtained by measurement $\left(\mathrm{E}_{\mathrm{exp}}\right)$ and by curve fitting $\left(\mathrm{E}_{\mathrm{fit}}\right)$. The curve fitting routine predicts a Young's Modulus; so agreement between this value and the experimental value is an indicator of a quality fit. 
WSRC-TR-2007-00437

Rev. 0

Table 3-2 Summary of the Results from the Beam Bending Experiments on Saltstone Mixes

\begin{tabular}{|l||c|c|c|c|c|c|c|c|}
\hline \multicolumn{7}{|c|}{ Tabulated Results from Bending experiments on MCU Saltstone samples } \\
\hline Sample Name & $\begin{array}{c}\text { Age } \\
\text { (Days) }\end{array}$ & $\begin{array}{c}\text { W(0) data } \\
(\mathrm{g})\end{array}$ & $\begin{array}{c}\mathrm{W}(0) \text { fit } \\
(\mathrm{g})\end{array}$ & $\begin{array}{c}\text { E exp } \\
(\mathrm{GPa})\end{array}$ & $\begin{array}{c}\text { E fit } \\
(\mathrm{GPa})\end{array}$ & $\begin{array}{c}\text { Max } \\
\text { Stress } \\
(\mathrm{MPa})\end{array}$ & $\begin{array}{c}\text { Permeability } \\
(\mu \mathrm{D})\end{array}$ & $\begin{array}{c}\text { Permeability } \\
(\mu \mathrm{D})\end{array}$ \\
\hline DMF_7-3_6mm & 6 & 65.9 & 65.1 & 2.43 & 2.40 & 0.1859 & 3.36 & 3.10 \\
\hline DMF_7-3_6mm_b & 15 & 91.1 & 91.1 & 2.78 & 2.78 & 0.244 & 1.53 & 1.44 \\
\hline DMF_6-26_5mm_b & 22 & 62.2 & 60.9 & 2.98 & 3.02 & 0.2276 & 0.983 & 0.771 \\
\hline DMF_6-26_6mm_b & 23 & 72.5 & 68.6 & 3.23 & 3.36 & 0.1762 & 2.14 & 1.55 \\
\hline DMF_6-26_5mm_c & 38 & 31.7 & 34.4 & 3.10 & 3.39 & 0.1578 & 0.976 & 0.677 \\
\hline DMF_7-3_10mm & 7 & 147.2 & 143.8 & 2.18 & 2.17 & 0.2004 & 5.32 & 6.05 \\
\hline DMF_6-26_10mm & 13 & 103.0 & 103.5 & 2.36 & 2.40 & 0.1768 & 4.07 & 3.87 \\
\hline DMF_6-26_9mm & 15 & 111.5 & 109.0 & 2.30 & 2.29 & 0.172 & 3.98 & 3.45 \\
\hline DMF_7-3_10mm_b & 29 & 144.8 & 141.5 & 3.04 & 2.43 & 0.1899 & 3.72 & 3.24 \\
\hline DMF_6-26_9mm_b & 35 & 100.8 & 118.9 & 2.31 & 1.96 & 0.1951 & 2.80 & 2.73 \\
\hline DMF_6-26_10mm_b & 36 & 134.9 & 123.8 & 2.91 & 2.23 & 0.2445 & 3.77 & 3.09 \\
\hline
\end{tabular}

The average permeabilities and corresponding hydraulic conductivities for the two plate thicknesses are presented in Table 3-3. In principle, these two values should be identical. However, the differences between them are still relatively small (a factor of 2.5). Additional testing will be required to resolve this issue.

Table 3-3 Average Permeabilities and Hydraulic Conductivities for MCU Mix Plates

\begin{tabular}{|c|c|c|c|}
\hline Age & $\sim$ Plate Thickness & Average Permeability & Hydraulic Conductivity \\
\hline days & $\mathrm{mm}$ & $\mathrm{nm}^{2}$ & $\mathrm{~cm} / \mathrm{sec}$ \\
\hline & & & $1.4 \mathrm{E}-09$ \\
\hline$>21$ & 5 & $1.4 \mathrm{E}-18$ & \\
\hline & & & $3.4 \mathrm{E}-09$ \\
\hline
\end{tabular}

These values of hydraulic conductivity are consistent with the values obtained earlier by Langton $^{20}$. Recently samples were prepared using MCU simulants and premix at a water to premix ratio of 0.60 and provided to Ken Dixon and Mark Phifer for measurement of hydraulic conductivities by outside laboratories. Although they have not published their results yet, the values they obtained were similar to the results obtained on the MCU based simulants using beam bending. 
The data on Young's modulus for these samples are also provided in Table 3-1. The measured values corresponded well with the predicted values obtained through the curve fitting routine. These values of Young's modulus show a stiffness for these MCU mixes that is significantly less than cured grout samples of OPC in water which have a Young's modulus that ranges from 10 to $25 \mathrm{GPa}$ depending upon the w/c ratio and curing time. It is interesting to note that porosity and Young's modulus are inversely related in that the modulus drops with increasing porosity. The measurement of porosity on these MCU samples is very high at $\sim 63 \%$ which is consistent with a low value of Young's modulus.

It is important to monitor the time dependence of permeability. In general, the permeability continues to decrease as the hydration reactions continue to occur. From previous work, it was shown that the degree of reaction of MCU mixes is relatively low at $\sim 33 \%$. On the other hand, it is known that OPC in water continues to react and that the degree of reaction approaches $100 \%$. Figure 3-4 shows the time dependence of the permeability of the 5 and $10 \mathrm{~mm}$ samples and of OPC in water. The OPC in water samples show significant decreases in permeability over time whereas the MCU mixes show a smaller effect presumably due to the fact that the degree of hydration in the MCU mixes is less than the OPC mixes.

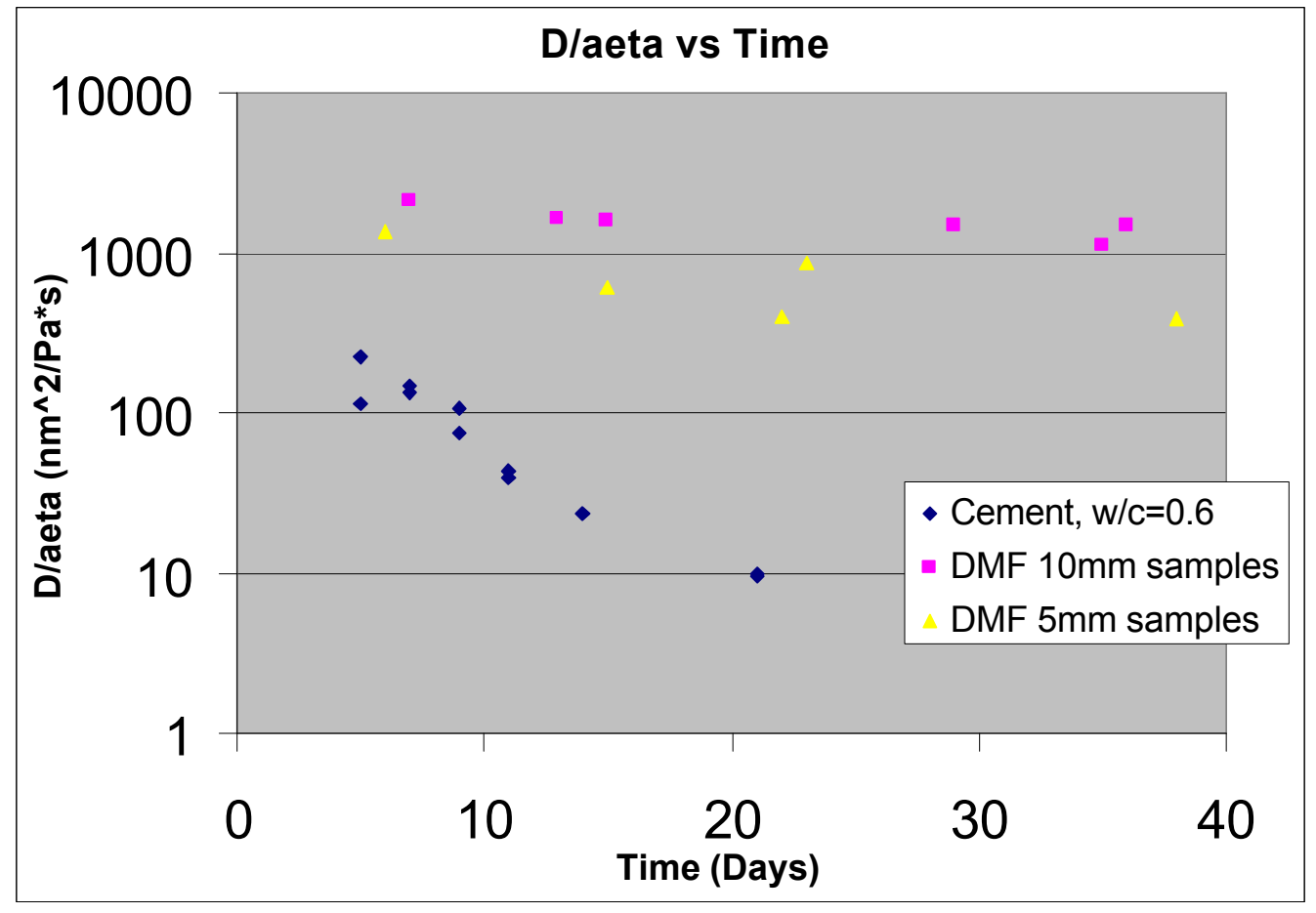

Figure 3-4 Permeability divided by viscosity of pore solution vs. time

Finally, the applied stress to the samples in the beam bending experiments is provided in Table 3-2. On average this stress is $0.2 \mathrm{MPa}$ which is equivalent to $\sim 30 \mathrm{psi}$. The data on the compressive strength of MCU mix over time are provided in Figure 3-5. 


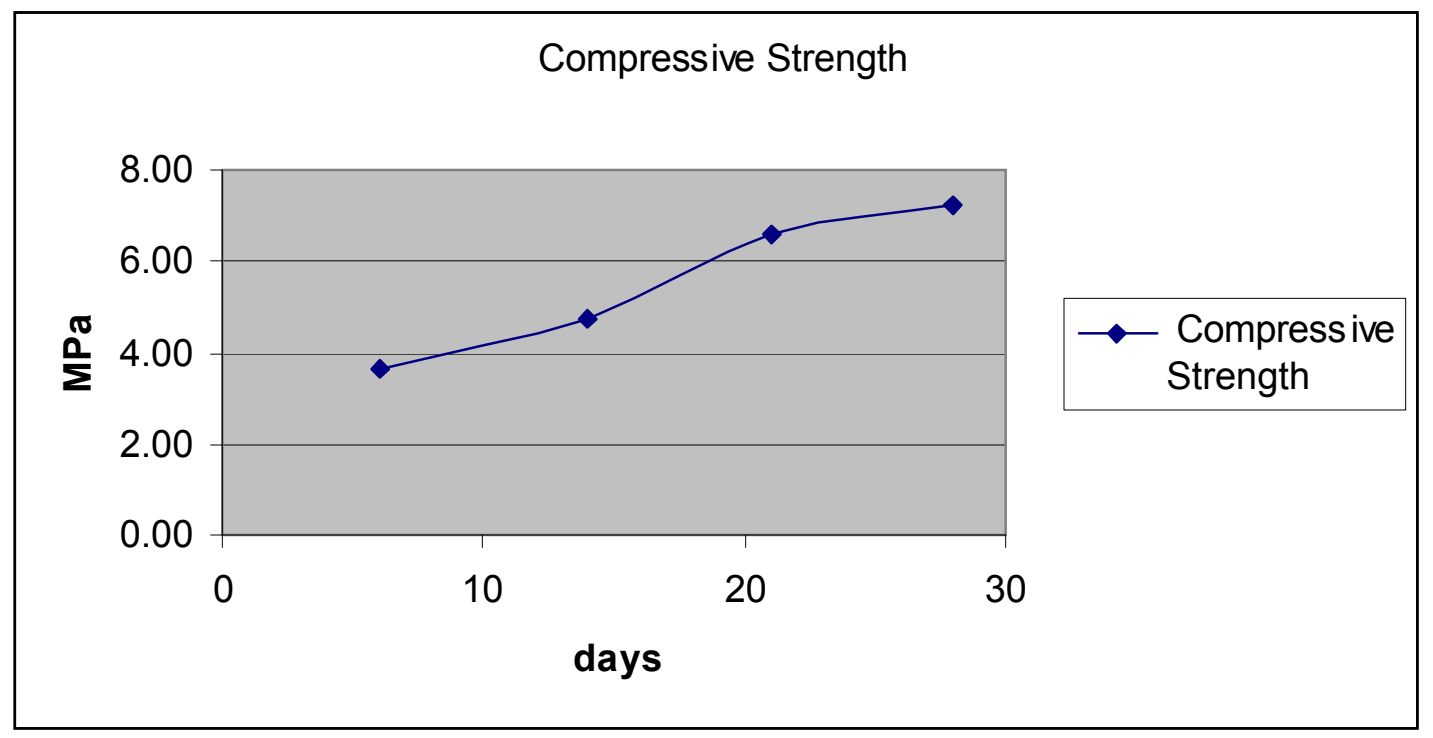

Figure 3-5 Compressive strength measurements as a function of cure time on MCU mix at 0.55 water to premix ratio.

In the beam bending experiments, the applied stress is maintained below the tensile strength to avoid damage to the plate during measurement. Typically, tensile strength is $\sim 1 / 10$ th of the compressive strength. Therefore for a compressive strength of $4 \mathrm{MPa}$, the maximum stress should be $0.4 \mathrm{MPa}$. The values in the table show that the stress applied was well below this value. Young's Modulus exhibits a similar trend (Figure 3-6) in the time dependence of the Modulus to the trend observed for compressive strength.

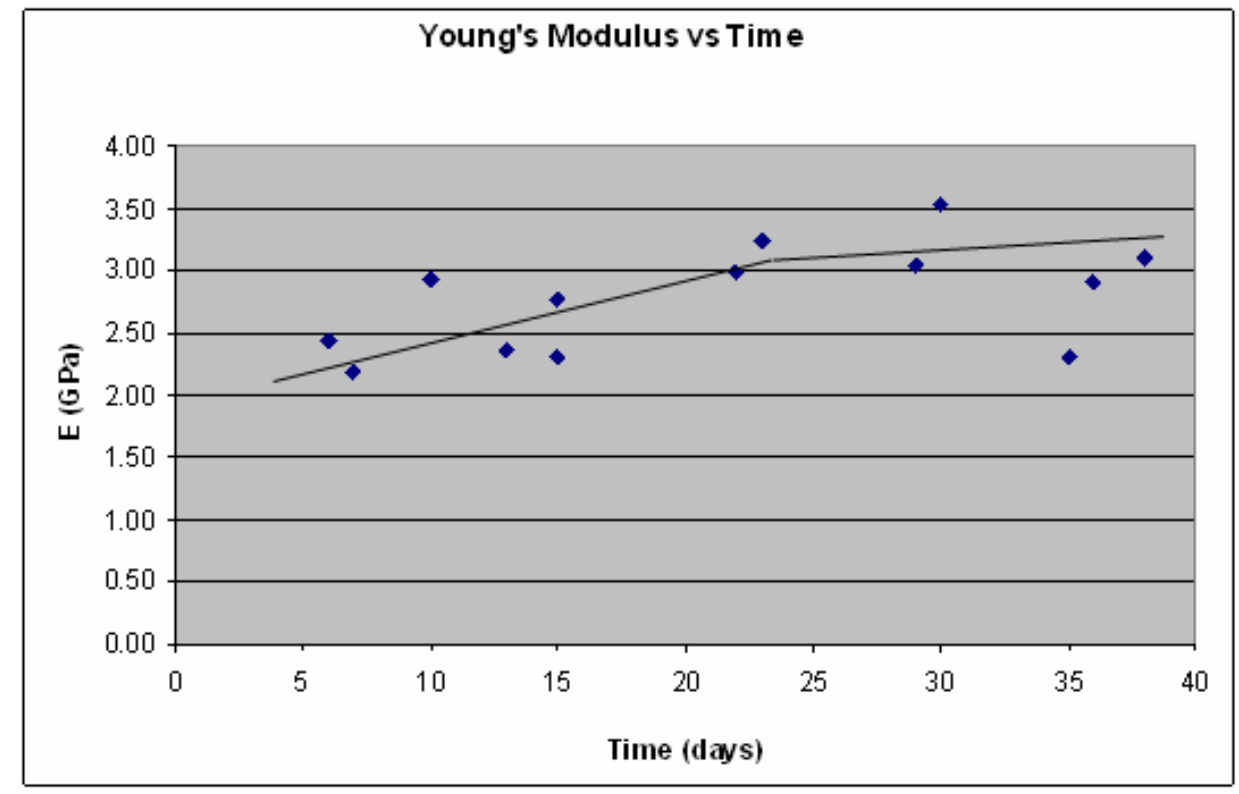

Figure 3-6 Young's modulus as a function of cure time on the 5 and $10 \mathrm{~mm}$ samples 
The hydration reactions can be followed by monitoring the heat of hydration as a function of time $^{21}$. Figure 3-7 shows this time dependence for an MCU grout containing premix at a water to premix ratio of 0.60 . After seven days, the heat of hydration is at a value of $110 \mathrm{~J} / \mathrm{g}$ which eventually levels off at $\sim 135 \mathrm{~J} / \mathrm{g}$. The calorimetric data correlate with the time dependence of the compressive strength and Young's modulus.

_ Signal, TR330-3, Normalized heat flow _ _ Signal, TR330-3, Normalized heat

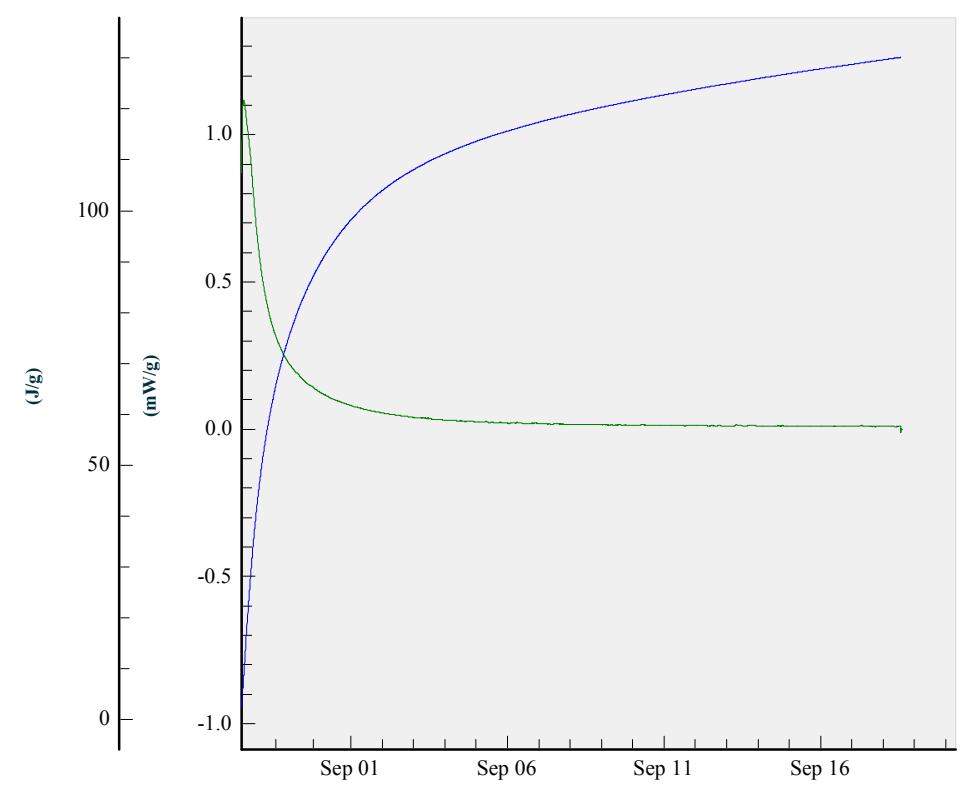

Figure 3-7 Heat of hydration data for a MCU in premix grout at 0.60 water to premix ratio 


\subsection{CONCLUSIONS}

This report summarizes the initial measurements of permeability and hydraulic conductivity on an MCU-based Saltstone mix. Conclusions are:

- The beam bending technique is feasible as a technique to measure the permeability and hydraulic conductivity of Saltstone mixes. The technique can readily measure the permeabilities in the range of interest quickly and inexpensively. In contrast, the measurement of hydraulic conductivity by conventional techniques is more difficult for samples with hydraulic conductivities in the range of $10^{-10}$ to $10^{-12} \mathrm{~cm} / \mathrm{sec}$.

- The initial hydraulic conductivity values obtained on samples that have cured up to 38 days ranged from 1.4 to $3.4 \times 10^{-9} \mathrm{~cm} / \mathrm{sec}$.

- The hydraulic conductivity values measured by beam bending experiments are consistent with independently measured values of the hydraulic conductivity on similar MCU-based mixes (made at ACTL), those measured by Dixon and Phifer and those measured by Langton.

- Young's modulus is on the order of $2.5 \mathrm{GPa}$, a value that is much lower than typical OPC water pastes and reflective of high porosity and low degree of hydration.

- The high porosity and low degree of reaction for the MCU mixes at 0.60 water to premix are consistent with a relatively high permeability as predicted and demonstrated in the literature for cementitious materials in water.

- The time dependence of the compressive strength and Young's modulus correlated well with the heat of hydration demonstrating the role of hydration reactions in determining the properties of Saltstone. 


\subsection{PATH FORWARD}

The recommended path forward includes:

- Develop a strategy for (1) transferring the methodologies for measurement and curve fitting and (2) installing the beam bending equipment at SRNL for use in the measurement of permeability and hydraulic conductivity of simulated Saltstone mixes. As part of the variability study, this technique will be used to determine those variables that most significantly drive the permeability.

- Determine the time dependence of the permeability of Saltstone samples to determine whether credit can be claimed for an improvement in permeability with time (relates to further hydration reactions). This beam bending technique can readily measure the time dependence over months/years using the same samples. 


\subsection{REFERENCES}

1. K.H. Rosenberger, B.C. Rogers, and R.K. Cauthen, "Saltstone Performance Objective Demonstration Document," Savannah River National Laboratory, Report No. CBU-PIT2005-00146, Revision 0

2. J.R. Harbour, V.J. Williams, T.B. Edwards, R.E. Eibling, and R.F. Schumacher, "Saltstone Variability Study -Measurement of Porosity," SRNL, Report No. WSRC-STI2007-00352, Rev. 0.

3. D.I. Kaplan and T. Hang, "Estimated Duration of the Subsurface Reducing Environment Produced by the Z-Area Saltstone Disposal Facility," SRNL, Report No. WSRC-RP2003-00362, Rev. 2.

4. D.I. Kaplan and T. Hang, "Estimated Duration of the Subsurface Reduction Environment Produced by the Saltstone Disposal Facility on the Savannah River Site," WM'07 Conference, (2007).

5. G.W. Scherer, J.J.V. II, and G. Simmons, "New Methods to Measure Liquid Permeability in Porous Materials," Cem. Concr. Res., 37, 386-397, (2007) (2007).

6. R.D. Hooton, " What Is Needed in a Permeability Test for Evaluation of Concrete Quality?," in Vol. 137, 1989, pp. 141-149., Pore Structure and Permeability of Cementitious Materials. Edited by L. R. Roberts and J. P. Skalny. Materials Research Society, Pittsburgh, 1989.

7. M.A. Phifer, M.R. Millings, and G.P. Flach, "Hydraulic Property Data Package for the EArea and Z-Area Soils, Cementitious Materials, and Waste Zones," Report No. WSRCSTI-2006-00198 Rev. 0, September, 2006.

8. K. Dixon and M. Phifer, "Hydraulic and Physical Properties of Tank Grouts for Ftf Closure," SRNL, Report No. WSRC-STI-2007-00369, Rev. 0, October 2007.

9. J.R. Harbour, T.B. Edwards, E.K. Hansen, and V.J. Williams, "Variability Study for Saltstone," Report No. WSRC-TR-2005-00447, October 2005.

10. G.W. Scherer, "Measuring Permeability of Rigid Materials by a Beam-Bending Method: I, Theory," J. Am. Ceram. Soc.,, 83 [9] 2231-39 (2000) (2002).

11. W. Vichit-Vadakan and G.W. Scherer, "Measuring Permeability of Rigid Materials by a Beam-Bending Method: Ii, Porous Glass," J. Am. Ceram. Soc., 83 [9] 2240-45 (2000) (2000). 
12. W. Vichit-Vadakan and G.W. Scherer, "Measuring Permeability of Rigid Materials by a Beam-Bending Method: Iii, Cement Paste," J. Am. Ceram. Soc., 85 [6] 1537-44 (2002) (2002).

13. W. Vichit-Vadakan and G.W. Scherer, "Measuring Permeability and Stress Relaxation of Young Cement Paste by Beam Bending," Cem. Concr. Res., 33 (2003) 1925-1932 (2003).

14. G.W. Scherer, "New Methods to Measure Permeability," Cementitious Materials for Waste Treatment, Disposal, Remediation and Decommissioning Workshop, (2006).

15. H.G.W. Taylor, Cement Chemistry, 2nd ed. Thomas Telford, 1997.

16. T. C. Powers and T.L. Brownyard, "Studies of the Physical Properties of Hardened Portland Cement Paste," J. Am. Concrete Inst, 43, 1947 (1947).

17. R.F. Feldman, Cement Technology, I. 3, 1972 (1972).

18. E.J. Garboczi, "Microstructure and Transport Properties of Concrete," in Performance Criteria for Concrete Durability. Edited by J. K. a. H. K. Hilsdorf. E \& FN Spon,, London, 1995.

19. T.C. Powers, L.E. Copeland, J.C. Hayes, and H.M. Mann, "Permeability of Portland Cement Paste," Portland Cement Association Report No. Bulletin 53, April, 1955.

20. C.A. Langton, "Saltstone Permeability (Hydraulic Conductivity)," Report No. DPST-85982, October 1986.

21. J.R. Harbour, V.J. Williams, and T.B. Edwards, "Heat of Hydration of Saltstone Mixes Measurement by Isothermal Calorimetry," Savannah River National Laboratory, Report No. WSRC-STI-2007-00263, Rev. 0, May, 2007. 